\title{
A novel locus for Usher syndrome type II, USH2B, maps to chromosome 3 at p23-24.2
}

\author{
M ounira H mani ${ }^{1}$, A bdelmonem G horbel $^{2}$, A mel Boulila-E lgaied ${ }^{1}$, Zeineb B en Zina ${ }^{3}$, \\ Wafa Kammoun ${ }^{2}$, M ohamed D rira', M ohamed Chaabouni ${ }^{3}$, Christine Petit ${ }^{4}$ and \\ $\mathrm{H}$ ammadi $\mathrm{A} \mathrm{yadi}^{1}$ \\ ${ }^{1} \mathrm{~L}$ aboratoire d'I mmunologie et de Biologie M oléculaire, Faculté de $M$ édecine, Sfax \\ ${ }^{2}$ Service D'ORL, CHU Bourguiba, Sfax \\ ${ }^{3}$ Service d'O phtalmologie, CHU B ourguiba, Sfax, Tunisia \\ ${ }^{4}$ U nité de G énétique des D éficits Sensoriels, CNRS URA 1968, Institut Pasteur, Paris, France
}

\begin{abstract}
U sher type II syndrome is defined by the association of retinitis pigmentosa, appearing in the late second to early third decade of life, with congenital moderate to severe non-progressive hearing loss. This double sensory impairment is not accompanied by vestibular dysfunction. To date, only one U sher type II locus, U SH 2A, at chromosome band 1q41, has been defined. Here, we demonstrate by linkage analysis, that the gene responsible for U sher type II syndrome in a Tunisian consanguineous family maps to chromosome 3 at position p23-24.2, thus providing definitive evidence for the genetic heterogeneity of the syndrome. A maximum lod score of 4.3 was obtained with the polymorphic microsatellite markers corresponding to loci D 3S1578, D 3S3647 and D 3S3658. This maps the gene underlying U SH 2B to a chromosomal region which overlaps the interval defined for the non-syndromic sensorineural recessive deafness DFNB 6, raising the possibility that a single gene underlies both defects. H owever, the audiometric features in the patients affected by U SH 2B and DFN B 6 are very different.
\end{abstract}

Keywords: U sher syndrome type II; homozygosity mapping; D FN B 6

\section{Introduction}

U sher syndrome represents a group of autosomal recessive disorders characterised by retinitis pigmentosa associated with congenital sensorineural hearing loss. The prevalence of this syndrome among profoundly deaf children may be as high as $8 \% .{ }^{1}$ Three clinical forms have been reported:

Correspondence: $\mathrm{H}$ A yadi, L aboratoire d'Immunologie et de $B$ iologie M oléculaire, Faculté de M édecine, 3018 Sfax, Tunisia. Tel: 2164246 946/216 4241888 ext. 350; Fax: 2164246 946

Received 9 September 1998; revised 6 November 1998; accepted 19 November 1998 (i) type I which is defined by congenital severe to profound, hearing loss, vestibular dysfunction, and development of retinitis pigmentosa during the first to early second decade;

(ii) type II which is characterised by congenital, moderate to severe, stable hearing loss, normal vestibular function, and appearance of retinitis pigmentosa in the late second to early third decade;

(iii) type III which associates progressive hearing loss and retinitis pigmentosa with a variable age of onset; ${ }^{1}$ vestibular troubles may occur in parallel to loss of auditory function. 
Clinical heterogeneity is accompanied by genetic heterogeneity. Six loci for U sher syndrome type I, U SH 1 (A to $F)$, have been reported mapping to chromosomes $14 q 32,{ }^{2} 11 q 13,{ }^{3,4} 11 p 15,{ }^{4} 10 q,{ }^{5} 21 q 21^{6}$ and $10,{ }^{7}$ respectively. O nly the gene responsible for U SH $1 B$ has been identified. ${ }^{8}$

The prevalence of $U$ sher type II syndrome in the general population in Europe and the USA has been estimated at $1 / 100000$. E vidence for genetic heterogeneity of this syndrome was reported several years ago, ${ }^{9}$ but only one locus, U SH $2 \mathrm{~A}$, has been identified to date. This locus maps to chromosome band $1 q 41^{10-12}$ and the corresponding gene has recently been identified. ${ }^{13}$ A ccording to a study performed on populations from England, I reland, Italy, The Netherlands, Spain, Sweden, Columbia and the USA, approximately $12.5 \%$ of families affected with U sher type II, fail to show linkage to chromosome band 1q41 (U SH 2A ). ${ }^{12}$

$\mathrm{H}$ ere, we report on the study of a consanguineous family originating from the south of Tunisia, affected with a typical type II form of U sher syndrome. G enetic linkage analysis using homozygosity mapping led us to identify a novel locus referred to as U SH $2 \mathrm{~B}$.

\section{Results and Discussion}

\section{Clinical Features}

A II members of family US, affected and unaffected, underwent a general audiological and ophthalmological clinical evaluation. A complete medical history was obtained for each affected individual. A ir-conduction pure-tone average (A CPTA) threshold in the conversational frequencies $(0.1,1$ and $2 \mathrm{kHz})$ was calculated for each deaf ear, and was used to define the severity of the hearing loss according to the better hearing ear: mild $(20 \mathrm{~dB} \leq \mathrm{ACPTA} \leq 39 \mathrm{~dB})$, moderate $(40 \mathrm{~dB} \leq \mathrm{ACP}$ TA $\leq 69 \mathrm{~dB})$, severe $(70 \mathrm{~dB} \leq \mathrm{ACPTA} \leq 89 \mathrm{~dB})$, and profound $(A C P T A \geq 90 \mathrm{~dB})$. A udiometry tests detected a moderate to severe sensorineural hearing loss in the affected individuals. Very similar audiometric sloping curves were observed in each patient, showing that the hearing loss predominates in the high frequencies; the values ranged from $20-50 \mathrm{dBHL}$ at $250 \mathrm{~Hz}$ to $70-95 \mathrm{dBHL}$ at $8000 \mathrm{~Hz}$, for the seven affected individuals. Ophthalmological examination detected the development of a retinitis pigmentosa in all deaf persons, with the appearance of night blindness occuring in the late second to early third decade. No vestibular dysfunction was noted using the caloric test, nor had a delay in the age of walking been noticed in any of the affected individuals. On the whole, the clinical signs observed in affected individuals in family $U \mathrm{~s}$, were indicative of a typical type II form of U sher syndrome. A II heterozygous carriers exhibited normal results for the audiometric tests, and for the ophthalmological examination.

\section{Linkage Analysis}

In the first instance, we tested the possible involvement of the sole locus already known to be associated with a type II form of U sher syndrome, U SH 2A . ${ }^{12} \mathrm{U}$ pon its elimination, given the possibility that a single locus might be responsible for different clinical forms of $U$ sher syndrome, we investigated the possible involvement of the other known USH loci: USH 1 (A to F $)^{2-7}$ and $\mathrm{U}$ SH $3 .{ }^{14} \mathrm{No}$ linkage could be detected between the disease and the polymorphic markers associated with these loci. We then tested the possibility of linkage with the DFNB (DFNB1 to DFNB 15) loci, which underlie isolated forms of autosomal recessive deafness. I ndeed, it has been shown that MYO7A, the gene encoding myosin VIIA, is responsible for both $U S H 1 B^{15}$ and an isolated form of recessive deafness, DFN B 2. ${ }^{8,16}$ D uring this exclusion mapping, linkage was observed with marker A FM 198yf2 (locus D 3S1289) which is located within the candidate interval defined for DFNB 6 at $3 p 24{ }^{17}$ E ight microsatellite markers were used to map the U SH 2 locus involved in U sher syndrome in family Us. Pairwise haplotypes and lod scores are shown in Figure 1. A maximum lod score of 4.3 was obtained at loci D 3S1578 and D 3S3658. H aplotypes are presented such as to minimise the recombination events occuring during meiosis. From the analysis of the data, we conclude that the gene responsible for the type II form of $U$ sher syndrome in family $U S$ is located in a chromosomal interval spanning a maximum distance of 23 CM , between D 3S1289 and D 3S1266. The haplotypes of the three affected siblings, IV-8, IV-9 and IV-10, in the absence of the possible analysis of the genotype of their mother (III-4), deserves further discussion. The U sher syndrome in III-4 might involve a different locus, and the $U$ sher syndrome in the three affected children might result from a digenism. H owever, the haplotypes of these patients in the chromosomal regions of the other U sher loci do not argue for their involvement, ie no evidence for homozygosity in these chromosomal regions could be obtained in the reconstituted genotype of III-4. M oreover, the phenotypes of the three affected individuals in branch III and in the other affected members are very similar. A Iternatively, the mother (III-4) and the father (III-3) might carry the same 
1

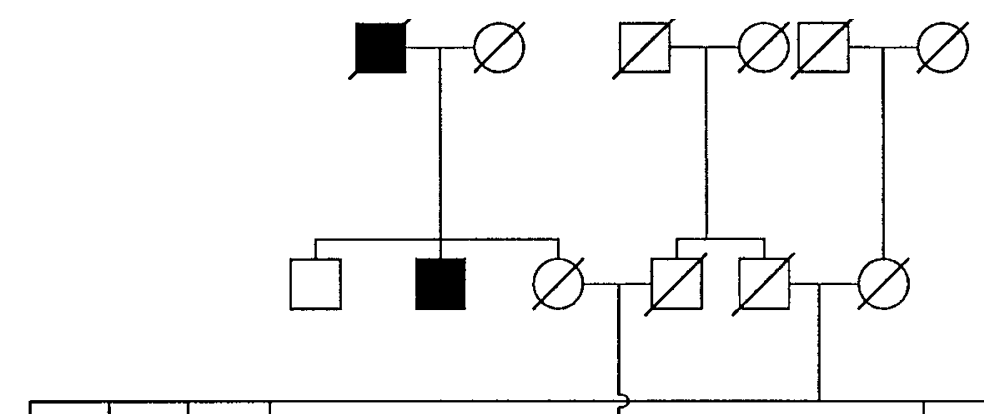

III<smiles>[GeH2]</smiles>

IV

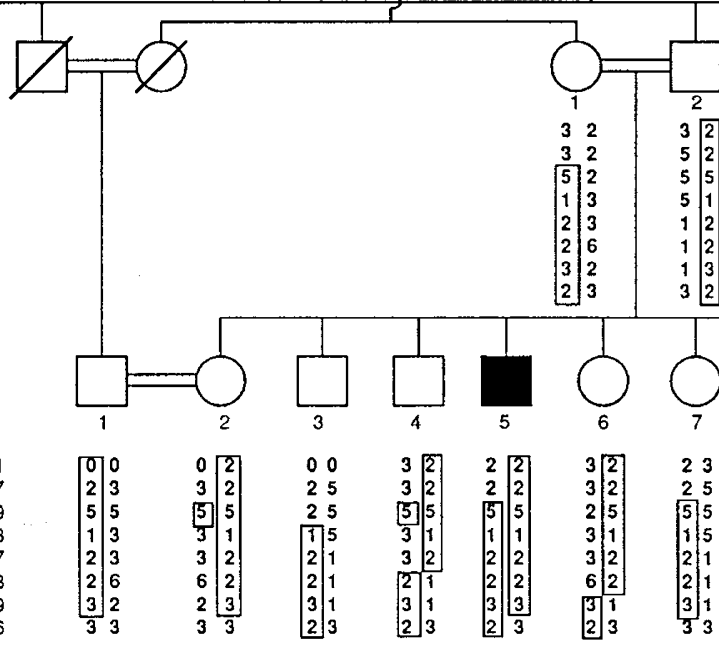

v

D3S3621
D3S3717
D3S1289
D3S1578
D3S3647
D3S3658
D3S 1619
D3S1266

\begin{tabular}{|l|ll|l|r}
0 & 0 & & 0 & 2 \\
2 & 3 & & 3 & 2 \\
5 & 5 & & 5 & 5 \\
1 & 3 & & 3 & 1 \\
2 & 3 & & 3 & 2 \\
2 & 6 & 6 & 2 \\
3 & 2 & & 2 & 3 \\
3 & 3 & & 3 & 3
\end{tabular}$\quad \begin{array}{rlll}2 & 2 & 5 \\
2 & 2 & 5\end{array}$

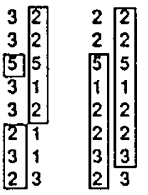

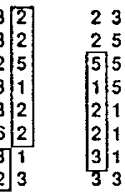

"I

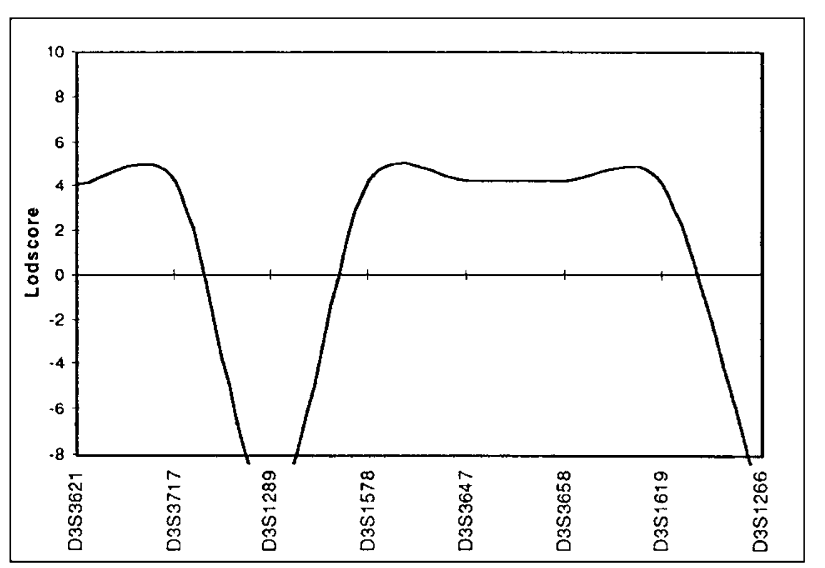

Figure $1 \mathrm{H}$ omozygosity by descent in a consanguineous Tunisian family affected with a form of U sher type II syndrome (USH 2B). $\mathrm{D}$ ark symbols correspond to affected individuals. The haplotype associated with U SH 2B is boxed. The genotypes of individuals IV-4, IV-6 and IV-11 can be explained by maternal double recombination events in the $27 \mathrm{cM}$ region between D $3 S 3717$ and D 351266 . The U SH 2B gene is localised between D 351289 and D $3 S 1266$ 
mutation. Since affected individuals share only a maternal allele, an allele of D 3S1578, this would leave a very small chromosomal region as candidate interval for the responsible gene. Several ancestral recombination events would have reduced the size of the homozygosity region. In this line, the recombinations flanking locus D 3S1578 observed in four out of seven siblings in generation IV support the idea of a high recombination activity in this particular chromosomal region.

The USH2B interval defined here overlaps over 14 CM (between D 3S1289 and D 3S1619) the distal part of the previously defined chromosomal interval for the isolated deafness DFNB 6, a $23 \mathrm{cM}$ interval extending between D $3 S 1766$ and D 3S1619 ${ }^{17}$ (see Figure 2). Therefore, the possibility that a single gene underlies both USH $2 B$ and DFNB6 should be considered. Such a situation has already been shown for USH $1 B$ and DFNB2, ${ }^{8,15,16}$ and may also apply to USHIC and DFNB $18^{4,18}$ or USH 3 and DFNB 15, ${ }^{14,19}$ which colocalise. In the frame of this hypothesis, a more deleterious mutation for USH2B than for DFNB 6 would be expected. However, in the single family affected with DFNB 6 described so far, affected individuals suffer from profound congenital deafness, ${ }^{17}$ whereas the reported USH $2 \mathrm{~B}$ family has the typical moderate to severe hearing loss characteristic of U sher type II syndrome. These audiometric data are more in favour of the existence of two different genes underlying USH $2 B$ and DFNB6. A large number of genes and EST s (up to 324 in Genome DataBase) have been mapped in the U SH 2B interval. In the absence of any potentially attractive candidate genes in the region, the search for U SH 2B itself will only be undertaken when the localisation interval has been narrowed down to an amenable size.

\section{Methods}

\section{Clinical Examination}

A consanguineous family, family $U \mathrm{~s}$, with marriages between first cousins (see Figure 1) living in the south of Tunisia, was studied. It comprises ten affected individuals, among whom eight are alive.

The diagnosis of $U$ sher syndrome in this family was established by an ophthalmological examination motivated by the appearance of night vision problems. R etinitis pigmentosa was diagnosed in affected individuals, based on concentric loss of visual field and granular accumulation of pigment at the ocular fundus. A udiometry tests were performed with a B elltone 2000 clinical audiometer on all family members. They consisted of pure-tone audiometry with air and bone-conduction at 250, 500, 1000, 2000, 4000 and

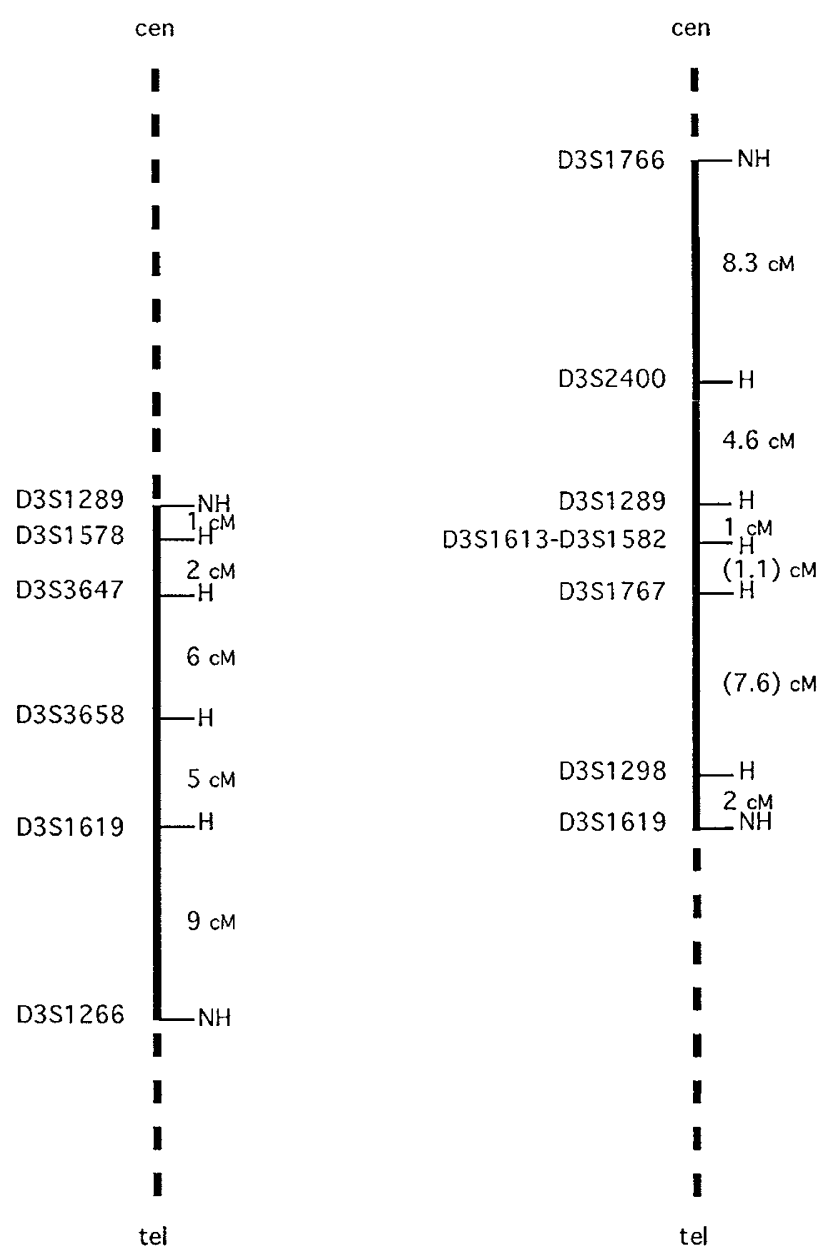

USH2B

DFNB6

Figure 2 Schematic representation of the part of chromosome 3 showing USH $2 B$ and DFNB 6 localisations. USH 2B and DFNB 6 candidate intervals overlap on a $14 \mathrm{cM}$ distance, between D 3S1289 and D 3S1619. H and NH represent respectively the homozygous and non-homozygous status of the microsatellite markers in the affected individuals (except individuals IV-8, IV-9 and IV-10)

$8000 \mathrm{~Hz}$. In addition, bilateral vestibular function was investigated by caloric stimulation.

\section{Genotyping}

G enomic D NA was extracted from $10 \mathrm{ml}$ blood samples using the standard phenol-chloroform technique. PCR amplifications on $60 \mathrm{ng}$ genomic D NA were performed using a Techne thermocycler, in a final volume of $50 \mu \mathrm{l}$ containing $2 \mu \mathrm{m}$ primers, $125 \mu \mathrm{m}$ dNTP, $1.5 \mathrm{~mm} \mathrm{M} \mathrm{gCl} 2,50 \mathrm{~mm} \mathrm{KCl}, 10 \mathrm{~mm}$ Tris$\mathrm{HCl} \mathrm{pH} 8.8$ and $1 \mathrm{U}$ Taq DNA polymerase. PCR products were run on a $6 \%$ polyacrylamide sequencing gel, transferred to $\mathrm{N}^{+}-\mathrm{H}$ ybond membrane (A mersham, UK) and hybridised with a poly A C probe labelled with $\alpha^{32}$-P-dCTP.

Polymorphic microsatellite markers from the Généthon collection were used. ${ }^{20}$ For the exclusion of linkage to 
previously identified loci, markers were chosen according to the panel indicated by the authors. The USH 2A locus has been excluded using AFM 205xd8 (locus D 1S237), A FM 280ycl (locus D 1S474) and A FM 196xh4 (locus $D$ 1S229). ${ }^{12} A$ putative linkage to the U sher type I ( $A$ to $F$ ) and type III loci was then investigated. In parallel, we tested a possible linkage to the loci corresponding to autosomal recessive forms of isolated deafness (DFNB forms).

\section{Linkage Analysis}

Lod scores were calculated using the MAPMAKER/ HOMOZ program ${ }^{21}$ (version 0.9), a computer package based on an algorithm especially designed for homozygosity mapping. U sher type II syndrome was assumed to be inherited in a recessive manner and coded as fully penetrant with a disease allele frequency estimated to $10^{-3}$. The lod score value was 4.3; changing the disease allele frequency to $10^{-2}$ only slightly modified the lod score value (4.2). The allele frequencies of the polymorphic markers and the meiotic recombination frequencies for males and females were assumed to be equal.

\section{Acknowledgements}

We are grateful to the family members for their participation in this study. We thank Sonia A bdelhak, Jean-Pierre $\mathrm{H}$ ardelin and Jacqueline L evilliers for critical reading of the manuscript and Sébastien Chardenoux for assistance in linkage analysis. This work was supported by Secrétariat d'E tat à la R echerche Scientifique et à la Technologie (Tunisia), AFM (France), CNRS-PICS and IN SER M -D GRST (France-Tunisia).

\section{References}

1 Gorlin RJ: Genetic hearing loss associated with eye disorders. In: Gorlin RJ, Toriello HV, Cohen MM (eds). Hereditary Hearing Loss and its Syndromes. Oxford U niversity Press: New York, Oxford, 1995, vol 28, pp 105-107.

2 Kaplan J, Gerber S, Bonneau D et al: A gene for $U$ sher syndrome type I (U SH 1A) maps to chromosome 14q. G enomics 1992; 14: 979-987.

$3 \mathrm{~K}$ imberling WJ, M öller C G, D avenport S et al: L inkage of $U$ sher syndrome type I gene (U SH 1B) to the long arm of chromosome 11. G enomics 1992; 14: 988-994.

4 Smith RJH, Lee EC, K imberling WJ et al: L ocalization of two genes for $\mathrm{U}$ sher syndrome type I to chromosome 11. G enomics 1992; 14: 995-1002.

5 Wayne S, Der Kaloustian VM, Schloss M et al: Localization of the U sher syndrome type 1D gene (U sh1D) to chromosome 10. H um M ol G enet 1996; 5: 1689-1692.

6 Chailb H, Kaplan J, G erber S et al: A newly identified locus for U sher syndrome type I, USH $1 E$, maps to chromosome 21q21. Hum Mol G enet 1997; 6: 27-31.
7 Wayne S, Lowry R B, M CL eod D R, K naus R, Farr C, Smith $\mathrm{RJH}$ : Localization of the $U$ sher syndrome type $1 \mathrm{~F}$ (U sh1F) to chromosome 10. Am J H um G enet 1997; 61: A 300.

8 Weil D, K üssel P, B lanchard et al: The autosomal recessive isolated deafness, DFNB2, and the U sher $1 B$ syndrome are allelic defects of the myosin-V IIA . N at G enet 1997; 16: 191- 193.

9 Pieke-Dahl S, Kimberling WJ, Gorin M B et al: Genetic heterogeneity of $U$ sher syndrome type II. J M ed Genet 1993; 30: 843-848.

10 Lewis R A, Otterud B, Stauffer D, Lalouel J -M, L eppert $M$ : $M$ apping recessive ophthalmic diseases: linkage of the locus for U sher syndrome type II to a DNA marker on chromosome 1q. G enomics 1990; 7: 250-256.

11 K imberling WJ, Weston M D, M öller CG et al: L ocalization of $U$ sher syndrome type II to chromosome 1q. Genomics 1990; 7: 245-249.

12 K imberling WJ, Weston MD, Möller CG et al: Gene mapping of $U$ sher syndrome type II A : localization of the gene to a 2.1-cM segment on chromosome 1q41. Am J H um G enet 1995; 56: 216-223.

13 Eudy JD, Weston M D, Y ao S et al: Mutation of a gene encoding a protein with extracellular matrix motifs in U sher syndrome type II. Science 1998; 280: 1753-1757.

14 Sankila E-M , Pakarinen $L, K$ ääriäinen $\mathrm{H}$ et al: $A$ ssignment of an U sher syndrome type III (U SH 3) gene to chromosome 3q. H um M ol G enet 1995; 4: 93-98.

15 Weil D, Blanchard S, Kaplan J et al: Defective myosin VIIA gene responsible for U sher syndrome type $1 B$. Nature 1995; 374: 60-61.

16 Liu X-Z, Walsh J, M buru P et al: M utations in the myosin VIIA gene cause non-syndromic recessive deafness. $\mathrm{N}$ at G enet 1997; 16: 188-190.

17 Fukushima K, Ramesh A, Srisailapathy CRS et al: A n autosomal recessive non-syndromic form of sensorineural hearing loss maps to 3p-DFNB6. Genome Res 1995; 5: 305-308.

18 Jain PK, Lalwani A K, Li XC et al: A gene for recessive nonsyndromic sensorineural hearing impairment (DFNB18) maps to the chromosomal region containing the U sher syndrome type $1 \mathrm{C}$ gene. Genomics 1998; 50: 290-292.

19 Chen A H, Wayne S, Bell A et al: New gene for autosomal recessive non-syndromic hearing loss maps to either chromosome $3 q$ or 19p. Am J Med Genet 1997; 71: 467-471.

20 D ib C, Fauré S, Fizames $C$ et al: A comprehensive genetic map of the human genome based on 5,264 microsatellites. Nature 1996; 380: 152-154.

21 Kruglyak L, Daly MJ, Lander ES: Rapid multipoint linkage analysis of recessive traits in nuclear families, including homozygosity mapping. A m J H um G enet 1995; 56: $519-527$. 